\title{
THE EFFECTIVENESS OF DIGITAL COMICS IN IMPROVING INDUSTRIAL REVOLUTION SKILLS AND STUDENT MOTIVATION
}

\author{
Kristin Sangur $^{1 *}$, Audrey Makatita ${ }^{2}$ \\ ${ }^{1}$ Biology Education Study Program, Faculty of Teacher Training and Education \\ Pattimura University, J1. Ir. M. Putuhena Ambon 97234, Indonesia \\ ${ }^{2}$ Postgraduate Alumni of Biology Education, Pattimura University, J1. Ir. M. Putuhena \\ Ambon 97234, Indonesia \\ *Corresponding Author: ${ }^{\text {sangur_kristin@yahoo.com }}$
}

\begin{abstract}
Digital comics are media that support the learning process in the 4.0 era. Digital comics contain the concept of bacteria that is easy for students to understand. The purpose of this study was to analyze the increase in problem-solving skills, critical thinking, and student motivation in learning the concept of bacteria using digital comics. The subjects in this study were 26 third semesters' students of the biology education program. The comics that are used are digital comics created by researchers using the comic life application. The instruments used were critical thinking test questions and problem-solving and motivation questionnaires. Data analyses were done by using descriptive analysis techniques. The results of the t-test analysis showed that there were differences in students' problem solving and critical thinking abilities before and after learning using digital comics "Bacterial Characteristics" ( $\mathrm{p}<0.05$ ). Meanwhile, student motivation also has differences between the first meeting and the second meeting during learning using digital comics $(\mathrm{p}<0.05)$. The use of digital comics can empower students' problem-solving skills, critical thinking, and motivation in learning the concept of bacterial characteristics.
\end{abstract}

Keywords: critical thinking, digital comic, motivation, problem solving

\section{Introduction}

In 2020, the world of education in Indonesia experienced a different situation due to the covid-19 virus. Thus, learning higher institutions also changes. The consequence that must be faced by lecturers and students is to start learning from home online. According to Abidah et al (2020), online or digital learning is in line with the era of industrial revolution 4.0 and community 5.0 with many advantages and disadvantages in the learning process. Furthermore, according to Yulia (2020), face-to-face learning has now been replaced by online learning. And that encourages educators to use various learning strategies to complete learning material, provide understanding to students, and improve online learning.

One way to make online learning effective for 5th-semester students of biology education FKIP UNPATTI during this pandemic is to use digital comics. According to Azman et al (2014), digital comics are a type of comic that uses technology to maintain quality, reduces physical space for storing books, is a file that is easily shared portable, or downloaded on websites. Wylie (2016) have succeeded in developing digital comics for Engineering Students to improve their abilities. Yulian (2018) also developed e-comicbased digital comics that can improve the quality of learning and are fun, so as to empower students' attention in understanding teaching material. The development of comics is based on their nature and types, namely interactive, two-dimensional, dynamic, easy to access, and carry because they are stored on digital devices such as smartphones, and are durable. Peterzen (2011) adds that the main difference is that printed comics have been converted to digital so that they can be read using certain electronic devices.

Also, the development of digital comics can attract students to learn. According to Ahmad (2012) elements in comics in the form of images, writings, and humor can attract and engage readers' emotions deeply. If comics are made digitally, interactive emotions

Received December $28^{\text {th }} 2020$, Revision February $06^{\text {th }} 2021$, Accepted for publication February $24^{\text {th }} 2021$.

Copyright (C) 2021 Published by FKIP - Unpatti, ISSN 2721-3110 
and thoughts between students as readers and comics can be created. This can increase student motivation to study, especially during this pandemic. Motivation to learn is an encouragement to learn. Motivation to learn can be created if learning is designed differently from learning that is usually followed by students. Research by Ranker (2007) shows that the motivation of students can increase when using comic book media in science learning. If digital comics are used as a learning medium in studying the concept of bacteria, then at the end of learning, students are also required to produce creative and innovative digital-based products.

If students are also assigned to make digital comics about bacteria, then students can work and develop problem solving skills and critical thinking. This happens because during the development of comics, students must understand how to use digital devices in the form of cellphones or computers as well as accessing the internet and even using information from the internet wisely. Critical thinking skills and problem solving are also needed in the learning process so that they can prepare students for the world of work in this era of industrial revolution 4.0. There are 10 skills in 2020, namely (1) problem solving, (2) critical thinking, (3) creative, (4) people management, (5) coordination with others, (6) emotional intelligence, (7) assessment and retrieval decisions, (8) service orientation, (9) bargaining, (10) cognitive flexibility (Gray, 2016). Problem solving and critical thinking skills are the top two skills needed by students in learning and the world of work.

The problem-solving process is a complex process that requires many skills used together (Saygili, 2017). Through problem-solving skills possessed by students, they become more motivated and provoke a sense of desire to solve existing problems. Cai and Lester (2010), problem-solving is one of the most important skills in which knowledge and skills are used at the highest level. According to Sutini et al (2017), the critical thinking process is formed through four stages, namely gathering information then evaluating it, making solutions, and making conclusions. Siburian et al (2019) explained that the empowerment of critical thinking skills is very dependent on the learning model and there is a relationship between critical thinking and concept understanding. Rumahlatu et al. (2020) added that the ability to think critically can support students' understanding of the material being taught.

Based on the opinions that have been submitted, it is a known fact that in the odd semester 2019/2020 academic year, it is known that $90.10 \%$ of students get a B grade with an average value of $75 ; 7.70 \%$ of students obtained an A grade with an average value of $85-88,2.20 \%$ of students obtained an E. The data shows that most students have obtained a satisfactory score, namely the grade of B. However, the average final score obtained by students is only 75 , and problem-solving and critical thinking skills have not been fully mastered by students. The value obtained by students of 75 is the standard value for getting a $\mathrm{B}$ grade and the final grade is an accumulation of activeness (10\%), assignments $(15 \%)$, Mid Terms (30\%), Finals (30\%), and practicum (15\%). Meanwhile, the learning and evaluation process also did not support the empowerment of student problem solving and critical thinking in learning basic microbiology. Therefore, the purpose of this study was to analyze the improvement of problem-solving abilities, critical thinking, and student motivation in learning the concept of bacteria using digital comics.

\section{Research and Method}

\subsection{Research Type}

This type of research is a descriptive study that aims to describe an increase in problem-solving and critical thinking and student's motivation in learning the concept of bacteria using digital comics.

Received December $28^{\text {th }} 2020$, Revision February $06^{\text {th }} 2021$, Accepted for publication February $24^{\text {th }} 2021$ Copyright (C) 2021 Published by FKIP - Unpatti, ISSN 2721-3110 


\subsection{Research subject}

The research sample was all class B class 2019 students who are currently in the third semester The number of students who became the research sample was 26 people.

\subsection{Instruments and procedures}

The instruments developed in this study were test questions accompanied by scoring rubrics and a motivation questionnaire. The scoring rubric is a list of criteria to measure problem-solving and critical thinking. Motivation questionnaires are provided for students to assess motivation during learning.

The research procedure is as follows: (1) making digital comics using the comic life application, comics containing material on the characteristics of bacteria. (2) Problemsolving and critical thinking-based pretests are given before the application of digital comics in learning. (3) Implementation of learning using digital comics. (4) During the learning process, students assess their motivation. (5) Problem-solving and critical thinking based posttests are given after the application of digital comics in learning.

\subsection{Data Analysis}

The research data were analyzed using descriptive statistics, namely the t-test. The t-test was used to analyze differences in students' problem solving and critical thinking abilities before and after learning, as well as differences between the I and II meetings during learning using digital comics "Bacterial Characteristics".

\section{Results and Discussion}

This digital comic "Characteristics of Bacteria" can be read using a mobile phone using the WPS office application or a PDF reader, making it easier for students to read and understand. The display of digital comics is seen in Figure 1.
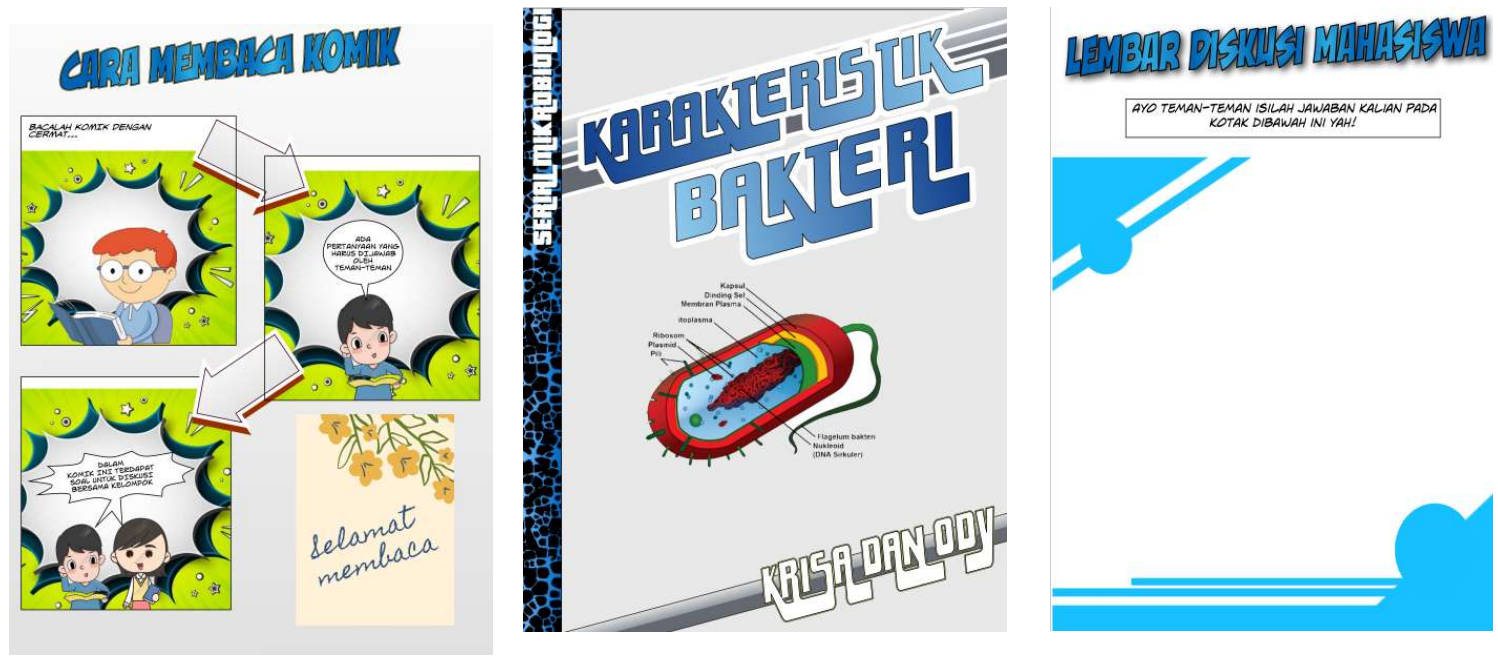

Received December $28^{\text {th }} 2020$, Revision February $06^{\text {th }} 2021$, Accepted for publication February $24^{\text {th }} 2021$

Copyright (C) 2021 Published by FKIP - Unpatti, ISSN 2721-3110 

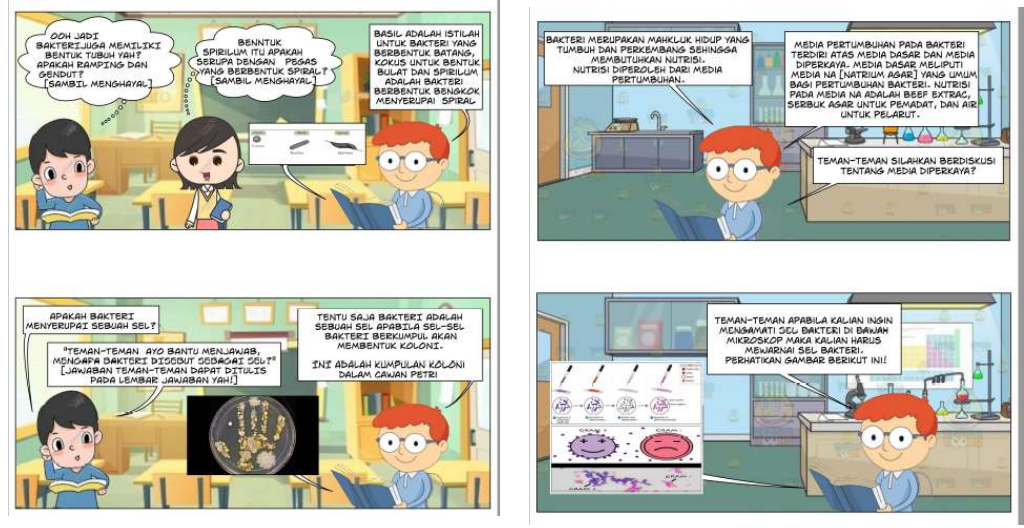

Figure 1. Display of digital comics from cover to comic content

The digital comic "Characteristics of Bacteria" consists of conversations in a language that is easily understood by students and empowers students to think and discuss events related to bacteria. The results of this study are the same as those conveyed by Azmi et al (2020) that android-based comics that have met valid requirements contain narratives and plots that can support students' critical thinking, they are also given LKPD as a means of discussion which contains questions about critical thinking about the material contained in the android comic. Furthermore, Manchester (2017) explains that comics for learning do not focus only on content but focus on activities and discussions through these comics.

The results of the t-test analysis showed that there were differences in students' problem solving and critical thinking abilities before and after learning using digital comics "Bacterial Characteristics" $(\mathrm{p}<0.05)$ (Table 1). Meanwhile, student motivation also has a difference between the first meeting and the second meeting during learning using digital comics $(\mathrm{p}<0.05)($ Table 1$)$.

Table 1. The results of the $t$ test analysis

\begin{tabular}{cccccc}
\hline Ability & Mean & Deviation Standard & $\mathrm{t}$ & $\mathrm{df}$ & Sig. \\
\hline Problem & -14.61538 & 2.13686 & -34.876 & 25 & .000 \\
solving & & & & & \\
Berpikir Kritis & -25.57692 & 2.64080 & -49.385 & 25 & .000 \\
Motivasi & -.61538 & 1.23538 & -2.540 & 25 & .018 \\
\hline
\end{tabular}

Digital comics contain questions for discussion and at the end of the meeting, students are assigned to create digital comics based on problem-solving and critical thinking. This is done so that the learning process can empower students' problem-solving skills and critical thinking. Through a series of questions to analyze a case can help students practice problem-solving skills (Rippen, et al., 2002). Meanwhile, Mourtos et al (2004) argue that problem-solving is defined as a process, used to obtain answers to a problem through a series of fact-finding and knowledge-finding. Through the process of reading comics, then discussing and practicing making digital comics students can empower their problem-solving skills related to bacterial material. Research by Syafii and Yasin (2013) shows that problem-based teaching materials can help improve students' problem-solving.

Learning using digital comics can also improve students' critical thinking (Table 1). The results of the same study were also conducted by Bolton-Gary (2012) using an alternative method in the form of comics that can guide students in constructing knowledge, creating understanding, increasing attention, critical thinking, and decision making.

Received December $28^{\text {th }} 2020$, Revision February $06^{\text {th }} 2021$, Accepted for publication February $24^{\text {th }} 2021$.

Copyright (C) 2021 Published by FKIP - Unpatti, ISSN 2721-3110 
Therefore, comic content that integrates conversation with critical thinking discussion can empower students' critical thinking skills in answering bacterial characteristics questions. According to Butera et al. (2014) teaching that integrates critical thinking in the process is more effective at supporting students in thinking. Sanders and Moulenbelt (2011) add that being a critical thinker they can analyze all facts, determine relevant or irrelevant facts, and synthesize the appropriate information. At the end of the lesson, students are also tasked with making digital comics containing questions to solve problems. At this stage, students are trained to become critical thinkers and problem solvers. Several studies have shown that the use of digital comics in learning can empower students' attention, explain new topics, simulate critical thinking, argue, be active in deduction, and link current learning with previous knowledge (Cheesman, 2006; Cimermanova, 2015; Koutnikova, 2017).

After going through the learning process using digital comics for two meetings, students can develop their abilities and become problem solvers and critical thinkers. Also, students show a developing interest in studying bacteria. This is indicated by the results of the motivation analysis at the first and second meetings that there was a significant increase (Table 1). The findings in this study are the same as research by Nikmah et al (2019) which states that comic media is very suitable for use in learning and can increase student motivation in studying Newton's gravitational force material. Crăciun and Bunoiu (2019) also have the same opinion that comic media can increase students' interest in learning.

\section{Conclusion}

Based on the explanation of the research results, the conclusion in this study is that the use of digital comics can improve problem-solving, critical thinking, and motivation of the 2019 third semester biology education program students in studying Bacterial Characteristics material.

\section{Acknowledgments}

This research was funded by the Faculty of Teacher Training and Education, Pattimura University, with Contract Number: 1592 / UN13 / SK / 2020.

\section{REFERENCES}

Ahmad, H. Aziz. 2012. The Impacts of Visual of Manga on Indonesian Readers' Psychological and Behavioral Reactions. Thesis. Chiba University. Published.

Azman, F.A., Zaibon, S.B., Shiratuddin, O. 2014. Exploring Digital Comics as an Edutainment Tool: An Overview. Knowledge Management International Conference (KMICe), 589-594. http://www.kmice.cms.net.my/

Azmy, W. N., Damayanti, A. E., Kuswanto, H. and Susetyo, B. 2020. Learning optics with android-assisted comics: the impacts on students critical thinking. Journal of Physics: Conference Series, 1440, 012055

Abidah, A., Hidaayatullaah, H. N., Simamora, R M., Fehabutar, D., Mutakinati, L. 2020. The Impact of Covid-19 to Indonesian Education and Its Relation to the Philosophy of "Merdeka Belajar". Studies in Philosophy of Science and Education (SiPoSE), 1(1):38-49.

Butera, G., Friesen, A., Palmer, S.B., Lieber, J., Horn, E.M., Hanson, M.J, dan Czaja, C. 2014. Integrating Mathematics Problem Solving and Critical Thinking Into the Curriculum. Young Children, 70-77.

Bolton-Gary, C. 2012. Connecting through Comics: Expanding Opportunities for Teaching and Learning, US-China Education Review B, 4, 389-395.

Crăciun, D \& Bunoiu, M. 2019. Digital Comics, a Visual Method for Reinvigorating Romanian Science Education. Romanian Journal for Multidimensional Education, 11(4): 321-341. DOI: 10.18662/rrem/172

Received December $28^{\text {th }} 2020$, Revision February $06^{\text {th }} 2021$, Accepted for publication February $24^{\text {th }} 2021$.

Copyright (C) 2021 Published by FKIP - Unpatti, ISSN 2721-3110 
Cai, J \& Lester, F. 2010. Why is Teaching with Problem Solving Important to Student Learning? Reston, VA: National Council of Teachers of Mathematics.

Cheesman, K. 2006. Using comics in the science classroom. Journal of College Science Teaching, 35(4), 48-53.

Cimermanova, I. 2015. Using Comics with Novice EFL Readers to Develop Reading Literacy, Procedia - Social and Behavioral Sciences, 174, 2452-2459, https://doi.org/10.1016/j.sbspro.2015.01.916

Gray, A. 2016. The 10 skills you need to thrive in the fourth industrial revolution. World Economic Forum. Retrieved from https://www.weforum.org/agenda/2016/01/the10- skills-you-need-to-thrive-in-the-fourth-industrial-revolution, diakses 10 Januari 2021.

Koutnikova, M. 2017. The Application of Comics in Science Education. Acta Educationis Generalis, 7(3):88-98, https://doi.org/10.1515/atd-2017-0026

Mourtos, N. J., Okamoto, N. D., \& Rhee, J. 2004. Defining, teaching, and assessing problem solving skills. ${ }^{7}$ th UICEE Annual Conference on Engineering Education, $1-5$.

Manchester, A. 2017. Teaching Critical Looking: Pedagogical Approaches to Using Comics as Queer Theory. SANE journal: Sequential Art Narrative in Education, 2(2):1-23.

Nikmah, S., Haroky, F., Jumadi, Wilujeng, I., and Kuswanto, H. 2019. Development of Android Comic Media for the Chapter of Newton's Gravity to Map Learning Motivation of Students. Journal of Physics: Conference Series, (1233), 012051. doi:10.1088/1742-6596/1233/1/012051.

Petersen, R. S. 2011. Comics, Manga, and Graphic Novels: A History of Graphic Narratives. Westport: Praeger Publisher.

Rippen, A., Booth, C., Bowie, S., \& Jordan, J. 2002. A complex case: Using the case study method to explore uncertainty and ambiguity in undergraduate business education. Teaching in Higher Education, 7(4), 429-435.

Ranker, J. 2007. Using comic books as read-alouds: Insights on reading instruction from an English as a second language classroom. The Reading Teacher, 61(4): 296-305.

Rumahlatu, D., Sangur, K., Liline, S. 2020. The Effect of Complex Instruction Team Product (CITP) Learning Model on Increase Student's Skills. International Journal of Instruction. 13(1): 587-606.

Sanders, M. \& Moulenbelt, J. 2011. Defining Critical Thinking: How Far Have We Come?. Inquiry: Critical Thinking Across the Disciplines, 26(1): 38-46.

Sutini, Sutawidjaja, A., Parta, I.N., Susanto, H. 2017. Identification of Critical Thinking Process in Solving Mathematic Problems. IOSR Journal of Research \& Method in Education (IOSR-JRME), 7(4):05-10

Saygili, S. 2017. Examining The Problem Solving Skills and The Strategies Used by High School Students in Solving Non-routine Problems, E-International Journal of Educational Research, 8(2): 91-114.

Syafii, W., \& Yasin, R. M. 2013. Problem Solving Skills and Learning Achievements through Problem-Based Module in teaching and learning Biology in High School, Asian Social Science, 9(12): 220-228.

Siburian J, Corebima A D, Ibrohim, \& Saptasari M. 2019. The Correlation Between Critical and Creative Thinking Skills on Cognitive Learning Results. Eurasian Journal of Educational Research, 81: 99-114.

Yulia, H. 2020. Online Learning to Prevent the Spread of Pandemic Corona Virus in Indonesia. Eternal (English Teaching Journal), 11(1): 1-12.

Yulian, V.N. 2018. Developing Teaching Materials Using Comic Media to Enhance Students' Mathematical Communication. IOP Conf. Series: Materials Science and Engineering 335: 012110 doi:10.1088/1757-899X/335/1/012110

Received December $28^{\text {th }} 2020$, Revision February $06^{\text {th }} 2021$, Accepted for publication February $24^{\text {th }} 2021$.

Copyright (C) 2021 Published by FKIP - Unpatti, ISSN 2721-3110 
Edu Sciences J. Vol. 2, No. 1. March 2021, 55-61

Wylie, C.D. 2016. Learning Out Loud (LOL): How Comics Can Develop the Communication and Critical Thinking Abilities of Engineering Students. Conference \& Exposition New Orleans, 1-19.

Received December $28^{\text {th }} 2020$, Revision February $06^{\text {th }} 2021$, Accepted for publication February $24^{\text {th }} 2021$

Copyright (C) 2021 Published by FKIP - Unpatti, ISSN 2721-3110 